Europ. Surg. Res. 1969;1:I-IV

\title{
Contents, Vol. 1, 1969
}

Europäische Chirurgische Forschung Recherches Chịrurgicales Européennes

Official Journal of the European Society for Experimental Surgery Offizielles Organ der Europäischen Gesellschaft für Experimentelle Chirurgie Organe officiel de la Société Européenne de Chirurgie Expérimentale

\section{Editorial Board:}

S. Bengmark, Göteborg; R. Benichoux, Nancy; S.-E. Bergentz, Göteborg; W. Brendel, Munich; R. Y. CALNE, Cambridge; U. F. GruBer, Basel; J. J. HAXHE, Louvain; F. LAR-GIADÈR, Zurich; C. MARCHAL, Nancy; N. A. MATHESON, Aberdeen; K. Messmer, Munich
BASEL (Schweiz)
S. KARGER
NEW YORK

Index

Abstracts of the 4th Congress of the European Society for Experimental Surgery

Davos, April 13-16, 1969

APPELGREN, L.: vide LEANDOER, L.

ARCHIMBAUd, J. P.: vide TRAEGER, J.

ARFORS, K.-E.: vide DHALL, D. P. 
BABOTAI, I.: vide HEGGLIN, J.

Benichoux, R.; Marchal, Chr.; Thibaut, G. and Heully, M. Cl. (Nancy):

Effects of Coronary Perfusions with THAM on Myocardial Anoxia of

in vivo Isolated Hearts

BERGENTZ, S.-E.: vide LEANDOER, L. vide LEWIS, D. H.

BERNHARDT, J. P.: vide TRAEGER, J.

BETUEL, H.: vide TRAEGER, J.

BONNET, P.: vide TRAEGER, J.

BOURKE, J. B.: vide MANN, C. V.

BRENDEL, W.; LAND, W.; FrICK, E. and Roscher, R. (Munich): The Effect of

Xenogenic Antilymphocyte Serum in Various Stages of Experimental

Allergic Encephalomyelitis. 253

BuI-Mong-Hung; Liacopoulos, P.; VigAno, M. et LEANDRI, J. (Paris): Homo-transplantation hétérotopique de cæur chez le rat: etude des stades

initiaux du rejet et influence de la conservation

vide Cachera, J. P. vide PERONNEAU, P.

CACHERA, J. P.; LACOMBE, M.; BuI-MONG-Hung; LACASSAgne, J. P.; CRePIn, Y.

and HatTAWAY, A. (Paris): AllogenicGraftsof the Heart in Dogs Treated

with an Anti-Dog Lymphocyte Serum or Globulin

CARIDIS, D. T.; GADDIE, J. and MATHESON, N. A. (Aberdeen): Continuous Per

toneal Lavage in Peritonitis.

CARRAZ, M.: vide TRAEGER, J.

CREPIN, Y.: vide CACHERA, J. P.

DEL CORRAL, J. F.: vide WENNERSTRAND, J. R.

Deloche, A.: vide Peronneau, P.

Dhall, D. P.; McKenzie, F. N.; Arfors, K.-E. and Matheson, N. A. (Uppsala):

Platelet Behaviour in Dogs During and After Moderate and Severe

Haemorrhage ...

Diomi, P.; MATHESON, N. A.; Norman, J. N.; RoBERTSON, J. W. and SHEARER,

J. R. (Aberdeen): Effects of Dextran 40 on Urine Flow and Composition

During Pronounced Reduction in Renal Perfusion...

ELIAS, M.: vide TOUSSAINT, C.

ENGESET, J. and MATHESON, N. A. (Aberdeen): Measurement of Red Cell Dispersion

in Surgical Patients.

FRICK, E.: vide BRENDEL, W.

FRIES, D.: vide TRAEGER, J.

GADDIE, J.: vide CARIDIS, D. T.

GALERA, R.: vide WENNERSTRAND, J. R.

HATTAWAY, A.: vide CACHERA, J. P.

Index

HEGGLin, J.; BABOTAI, I. and LARGIADÈR, F. (Zurich): The Influence of Vagotomy

on Elektrogastromyography 56

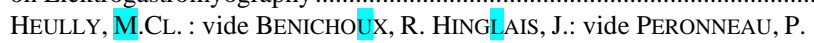

HugGins, C. E. (Boston): Frozen Blood

j ACOBSSOn, B. (Göteborg): Effect of Vascular Catheterisation on Platelet Adhesiveness 290 KinnAERT, P.: vide TOUSSAINT, C. KÖHnLEIN, H.

E.: vide Lemperle, G. LaCAssagne, J. P.: vide CACHERA, J. P. LACOMBE, M.: vide CACHERA, J. P. LAND, W.: vide BRENDEL, W. LARGIADÈR, F.: vide HEgGlin, J. LAURENT, D.: vide MilHaud, A.

LEANDOER, L.; APPELGREN, L. and BergentZ, S.-E. (Göteborg): Fibrinogen Turn

over after Massive Haemorrhage in Heparinized Dogs

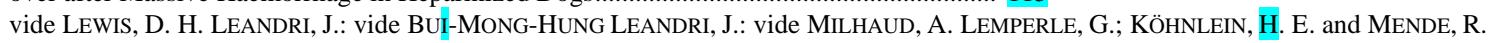

(Freiburg): Prolonged Survival of

Skin Allografts after Treatment with Direct Current

50

LEWIS, D. H.; BERGENTZ, S.-E. and LEANDOER, L. (Göteborg): The Effect of Red Cell

Aggregation on the Transit Time of Cells and Plasma through the Kidney 13 LiACOPOULOS, P.: vide BUI-MONG-HuNG

Mann, C. V.; Bourke, J. B. and Swann, J. C. (London): The Reversed Duodenum as an Alternative to the Henley Procedure after Partial

Gastrectomy; an

experimental study

64

Marchal, Chr. : vide Benichoux, R. Matheson, N. A.: vide Caridis, D. T. vide Dhall, D. P. vide Diomi, P. vide Engeset, J. McKenzie, F. N.: vide Dhall, D. P. MENDE, R.: vide Lemperle, G. METZ, R. and SEEGER, W. (Giessen): Collagen Wrapping of Nerve Homotransplants in Dogs. A preliminary report . 157

MiKAELOFF, P.: vide RASSAT, J. P.

Milhaud, A.; Leandri, J.; Pariente, R. and Laurent, D. (Paris): Preliminary

Experiments of Canine Isolated Lung Perfusion for Storage ... 126

MonsaingeOn, A. and SchIRAR, M. (Villejuif): Changes in Electrical Potentials

Within the Liver and the Kidneys During Acute Surgical Conditions 299 Norman, J. N.: vide DIOMI, P. PARIENTE, R.: vide MilHAUd, A.

Peronneau, P.; Deloche, A.; Bui-Mong-Hung et Hinglais, J. (Paris): Débit- 
métrie ultrasonore - Développements et applications expérimentales . 147 Perrin, J.: vide Traeger, J. PhilipPe, M.: vide RASSAT, J. P. PREVOt, J.: vide Traeger, J. Randall, H. T.: vide TAMVAKopoulos, S. K. Rassat, J. P.; PhilipPe, M.; MiKaeloff, P. and SASSARD, J. (Lyon): An Apparatus

for Hypothermic Perfusion of Isolated Kidneys 97

RitTMANN, W. W. and SMith, L. L. (Basel/Loma Linda): Cerebral Venous Out

flow During Graded Hemorrhage

index

ROBERTSON, J. W.: vide Dl̈OMI, P.

ROSCHER, R.: vide BRENDEL, W.

SASSARD, J.: vide RASSAT, J. P.

SAUBIER, E.: vide TRAEGER, J.

SCHIRAR, M.: vide MONSAINGEON, A.

SEEGER, W.: vide METZ, R.

SHEARER, J. R.: vide DIOMI, P.

SMITH, L. L.: vide RITTMANN, $\mathrm{W}$. W.

SWANN, J. C.: vide MANN, C. V.

TAmVaKopoulos, S. K.; RANDAll, H. T. and VanLanCKeR, J. (Providence): DNA

and Protein Metabolism After Liver Autotransplantation.....

THIBAUT, G.: vide BENICHOUX, R.

TOUSSAINT, C.; KINNAERT, P. and ELIAS, M. (Bruxelles): Immune Responses after

Intralymphatic Injection of ${ }^{32} \mathrm{P}$-Chromium Phosphate in the Dog ... 37

Traeger, J.; Fries, D.; PerRIN, J.; CARRAZ, M.; SAUBIER, E.; BONNET, P.; ARCHIM-

BAUD, J. P.; BernhARDT, J. P.; BETUEL, H.; VEYSSERE, C. and PREVOt, J.

(Lyon): The Results of the Use of Antilymphocytic Globulins in Human

Kidney Transplantation

VANLANCKER, J.: vide TAMVAKOPOULOS, S. K.

VEYSSERE, C.: vide TRAEGER, J.

VigANO, M.: vide BUII-MONG-HuNG

Wennerstrand, J. R.; Galera, R. and Del Corral, J. F. (Stockholm): An Experimental Method for the Intraluminal Occlusion of Arterial Aneurysms . 309

All rights, including that of translation into other languages, reserved.

Photomechanic reproduction (photocopy, microcopy) of this volume or parts thereof without special permission of the publishers is prohibited.

(c) Copyright 1969 by S. Karger AG, Basel

Printed in Switzerland by Buchdruckerei National-Zeitung AG, Basel

Cliches: Steiner \& Cie. AG, Basel 